\title{
Combination treatment of Cetuximab and photodynamic therapy in SNU-1041 squamous cancer cell line
}

\author{
SUN GON KIM ${ }^{1}$, JI WON HONG ${ }^{1}$, SUNG HYUN BOO ${ }^{1}$, MYUNG GU KIM ${ }^{1}$, KANG DAE LEE $^{2}$, JIN CHUL AHN ${ }^{3}$, \\ HEE JUN HWANG ${ }^{3}$, JANG-IN SHIN ${ }^{3}$, SANG JOON LEE ${ }^{4}$, JANG KEUN OH ${ }^{4}$ and PHIL SANG CHUNG ${ }^{1}$ \\ ${ }^{1}$ Department of Otorhinolaryngology-Head and Neck Surgery, Masan Samsung Medical Center, Sungkyunkwan University \\ School of Medicine, Masan; ${ }^{2}$ Department of Otorhinolaryngology-Head and Neck surgery, Kosin University College of \\ Medicine, Gospel Hospital, Busan; ${ }^{3}$ Medical Laser Reserch Center, ${ }^{4}$ Department of Otorhinolaryngology-Head \\ and Neck surgery, College of Medicine, Dankook University, Cheonan, Korea
}

Received January 28, 2009; Accepted March 30, 2009

DOI: $10.3892 /$ or_00000490

\begin{abstract}
Cetuximab (Erbitux) has been highlighted for its anti-proliferative effects in solid tumors and it is currently used as an adjuvant modality with other anti-cancer treatments. Photodynamic therapy (PDT) is used widely in many specialties of medicine. This study evaluated the efficacy of a combination treatment of two modalities (Cetuximab, PDT) both in vivo and in vitro. The SNU-1041 cell line was used for both the in vitro and in vivo studies. The in vivo and in vitro experiments were each classified into four groups, control group, Cetuximab applied group, PDT applied group and combined modality group. A migration study was performed to determine the anti-migration effect of Cetuximab, and a MTT assay was performed to compare the anti-proliferative effect of the modalities in vitro. For the in vivo study, the cells were implanted into 5-week-old nude mice. The measured volume of the tumor for each group was compared as a function of time. In the migration study, the control group showed a longer migration length than the Cetuximab applied group. In the MTT assay, the combination modality group showed less survival than the uni-modality groups. The measured tumor size after treatment showed that the combination treatment was more effective than the single modalities. PDT and Cetuximab are treatment modalities that target different molecular pathways. A combination of these two treatment modalities was found to more effective than an individual treatment. However, further studies will be needed to determine the optimal dose of the photosensitizer and Cetuximab.
\end{abstract}

Correspondence to: Dr Phil Sang Chung, Department of Otorhinolaryngology-Head and Neck Surgery, College of Medicine, Dankook University, Cheonan, Korea

E-mail: pschung@dankook.ac.kr

Key words: Cetuximab, photodynamic therapy, head and neck cancer cell lines

\section{Introduction}

The Epidermal Growth Factor (EGF) combines the EGF receptor $(\mathrm{R})$ that exists in the cell membrane and delivers a signal inside the cell that promotes cell division. EGFRs are found on the cell membranes attached to a phosphoglycoprotein with a molecular weight of $170 \mathrm{kDa}$. The intracellular area exhibits tyrosine kinase activity in the part where the extracellular area of the EGF is. If EGF and EGFR are combined, cell division and proliferation occur to phosphorylate a large number of target proteins. In addition, it has been reported that EGFR is associated with an increase in tumorigenesis because EGF promotes cell division, and works through EGFR. EGFR has been observed in various normal human body organizations, such as the skin, muscle, pancreas, breast, prostate, but not in hematopoietic cells (1).

EGFR is related to malignant changes in human brain cancer and poorly differentiated or invasive bladder cancer, and has been observed in colon and rectal cancer (2-5). In addition, the overexpression of EGFR suggests an increase in cell proliferation. Therefore, EGFR has attracted a great deal of attention as a tumor marker indicating a poor prognosis.

Cetuximab (Erbitux, C225) is a monoclonal antibody of EGFR and has been studied extensively in a large number of preclinical or clinical experiments $(6,7)$. A preclinical study showed that Cetuximab can inhibit the proliferation of colon, head and neck, and pancreatic cancer (8-10). In addition a comparison of a combined radiation-Cetuximab group with a radiation only group of head and neck cancer patients in a three-stage clinical experiment revealed an extended survival period in the combined radiotherapy group (11). The synergistic effect of DNA damaging factors, such as Cetuximab, anti-cancer drugs and radiotherapy has attracted considerable attention. In particular, a combination therapy of Cetuximab and irinotecan to colon cancer patients showing no response to irinotecan recently received approval from the FDA (12).

Photodynamic therapy (PDT) was recently introduced as an anticancer treatment with excellent treatment effects, and is used widely in a similar manner to radiotherapy or chemotherapy. Photodynamic therapy destroys cancer after being 
photosensitized to light of a specific wavelength by the administration of a photosensitizer (13-15). The development of a photosensitizer with the optimal treatment effect and minimal side effects is important. The intracellular distribution of a photosensitizer is affected by physical chemical properties, such as the molecular weight of the photosensitizer, and quantity of electric charge during photodynamic therapy (16). A lipophilic photosensitizer migrates after combining with serum lipoprotein, is absorbed through intracellular endocytosis after combining with the LDL receptor of a cell and accumulates mainly in the endoplasmic mitochondria, endoplasmic reticulum, nucleus, and lysosomes (17). In addition, the response of a cell appearing after photodynamic therapy differs according to the type of photosensitizer, method used and type of a tumor cell (18). Photofrin is a recently derived hematophorphyrin derivative that has gradually improved its coverage as photosensitizer with a variety of effects reported (19). This study compared the synergic effect of Cetuximab, which inhibits the growth of tumor cells, when used in conjunction with photodynamic therapy, which is being used increasingly as a new anticancer treatment both in vitro and in vivo.

\section{Materials and methods}

A chemical reagent, photosensitizer and a laser. The photofrin was used as the photosensitizer in the in vitro and in vivo experiments, and a $632 \mathrm{~nm}$ diode laser (Biotec AG, Jena, Germany) was used as the light source. Cetuximab (ImClone Systems Inc., New York, NY, USA) was used undiluted (2 $\mathrm{mg} / \mathrm{ml})$.

Cell culture. The SNU-1041 squamous cancer cell line of the head and neck, was cultured in a culture flask (Nunc, Denmark) containing $500 \mathrm{ml}$ of RPMI (Gibco BRL, Grand Island, NY, USA) mixed with $50 \mathrm{ml}$ of fetal bovine serum (Gibco BRL), and $5.5 \mathrm{ml}$ of antibiotic antimycotic (Gibco $\mathrm{BRL})$ in a $5 \% \mathrm{CO}_{2}$ incubator.

Anti-growth effect of Cetuximab for SNU-1041 cell. A MTT assay was used to evaluate the cytotoxic effect of Cetuximab on SNU-1041 cells. SNU-1041 cells in the exponential period were grown to $10^{5}$ cells $/ \mathrm{ml}$ and diluted with the culture medium. The cells were then grown in a 96-well plate at $100 \mu 1$ per well in a $5 \% \mathrm{CO}_{2}$ thermo-hygrostat. The cells were divided into 5 groups; a control group and four density groups $(3.9,31.3,250,500 \mu \mathrm{g} / \mathrm{ml})$. The cells were cultured for approximately $48 \mathrm{~h}$. Subsequently, $50 \mu \mathrm{l}$ of pH 7.3 DPBS MTT[3-(4,5-dimethylthiazol-2-yl)-2,5-diphenyl-tetrazolium bromide] ( $2 \mathrm{mg} / \mathrm{ml}$, Sigma, St Louis, MO) was added to each well and cultured in a thermo-hygrostat for $4 \mathrm{~h}$. After culturing, the culture medium was removed from each well and $150 \mu \mathrm{l}$ of DMSO was added. The wells were shaken for $5 \mathrm{~min}$ and the formazan was melted using a microplate mixer (Amersham Pharmacia Biotech, Sweden). The optical density of formazan was measured at $540 \mathrm{~nm}$ using a microplate reader (Bio-Rad Laboratories Inc., Hercules, CA, USA). The survival rate was calculated using the following formula, and statistical analysis was carried out using a statistical package.

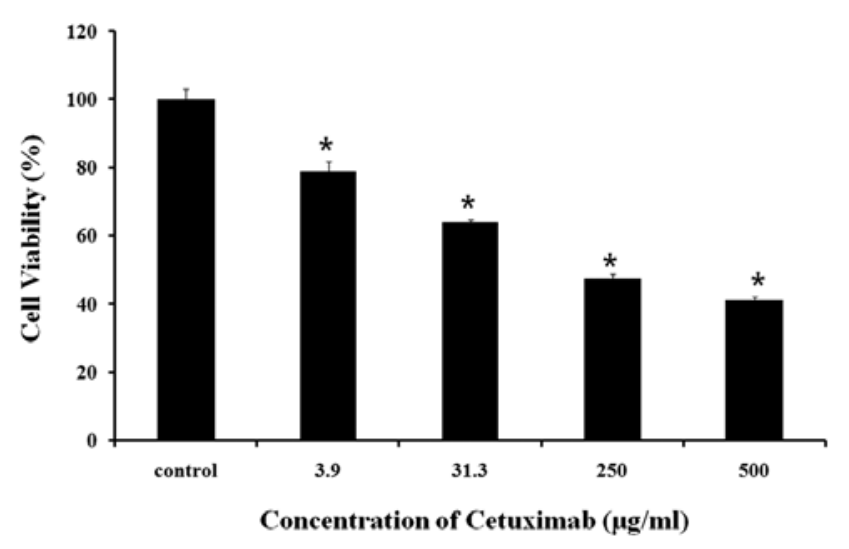

Figure 1. The antiproliferative effect of Cetuximab in SNU-1041 human head and neck squamous cancer cells. The viability of SNU-1041 cells treated with Cetuximab decreased in a dose-dependent manner.

Cell viability $(\%)=\frac{\text { Mean optical density in the test well }}{\text { Mean optical density in the control well }} \times 100$

Cell migration assay. The SNU-1041 cells were cultured until the monolayer was $70-80 \%$ confluent in a culture flask (Nunc). The culture medium was then removed, and a regular distance between cells of approximately $1.2 \mathrm{~mm}$ was made in flask using the yellow tip of a pipette. After washing the cells that failed in the DPBS solutions $(0,2,20$ and $200 \mu \mathrm{g} / \mathrm{ml}$ ) Cetuximab at different concentration was then added. The distance was measured at 0, 12, 24, 36, 48 and $72 \mathrm{~h}$ from photographs, using a digital camera (Samsung, Korea) and the degree of cell migration was compared.

The synergistic effect of Cetuximab and photodynamic therapy. SNU-1041 cells in the exponential period were grown to $10^{5}$ cells $/ \mathrm{ml}$. After diluting the cells with the culture medium, $100 \mu 1$ per well of the cells were added to four 96well plates and cultured in a $5 \% \mathrm{CO}_{2}$ thermo-hygrostat. After adding Cetuximab to the four plates at the set concentration $(50,125,250$ and $500 \mu \mathrm{g} / \mathrm{ml})$, photofrin, which was diluted from 1.0 to $0.001 \mathrm{mg} / \mathrm{ml}$, was added. After $6 \mathrm{~h}$, the upper $10 \mathrm{~cm}$ area of the plates was exposed to $632 \mathrm{~nm}$ diode laser light $\left(3.2 \mathrm{~J} / \mathrm{cm}^{2}\right)$. After exposure, the culture medium was changed, and the same concentration of Cetuximab was added. After $48 \mathrm{~h}$, the groups treated individually with either photodynamic therapy or Cetuximab were compared with the groups treated with both photodynamic therapy and Cetuximab.

Protein extraction and Western blotting. The SNU-1041 cells were divided into six groups. Group 1 was the control group. Group 2 was treated with $3.9 \mu \mathrm{g} / \mathrm{ml}$ of Cetuximab. Group 3 was treated with photodynamic therapy at a photosensitizer concentration of $0.8 \mu \mathrm{g} / \mathrm{ml}$. Group 4 was treated with photodynamic therapy at a photosensitizer concentration of $3.1 \mu \mathrm{g} / \mathrm{ml}$. Group 5 was treated with photodynamic therapy and $3.9 \mu \mathrm{g} / \mathrm{ml}$ Cetuximab at a photo-sensitizer concentration $0.8 \mu \mathrm{g} / \mathrm{ml}$. Group 6 was treated with photodynamic therapy and $3.9 \mu \mathrm{g} / \mathrm{ml}$ Cetuximab at a photo-sensitizer concentration 
of $3.1 \mu \mathrm{g} / \mathrm{ml}$. After culturing for $24 \mathrm{~h}$, the protein was extracted and treated with a RIPA buffer (Sigma). The protein was analyzed using the Bradford assay (Bio-Rad). A protein of equivalence was placed in the sample buffer solution, boiled for $5 \mathrm{~min}$, and loaded onto $10 \%$ polyacrylamide gel. SDS-PAGE electrophoresis was performed at $100 \mathrm{~V}$. Subsequently, the protein in the polyacrylamide gel was shifted to a PVDF membrane (Bio-Rad) at $100 \mathrm{~V}$ for 90 min. The PVDF membrane was placed in a PBST buffer solution $(0.1 \%$ Tween-20 in PBS) that included $5 \%$ non-fat dry milk and shaken for $1 \mathrm{~h}$ at a normal temperature. The first antibody EGFR (Santa Cruz Biotechnology Inc., Santa Cruz, CA, USA) was added at $4^{\circ} \mathrm{C}$ for $24 \mathrm{~h}$. After cleaning the PVDF membrane 3 times with a PBST buffer solution for 15 min each, the HRP-conjugated second antibody, which suited the 1st antibody, was added at a normal temperature for $1 \mathrm{~h}$. The sample was washed again 3 times with a PBST buffer solution for $15 \mathrm{~min}$ each. The samples were then reacted in an ECL kit (Amersham, UK), and analyzed using an image analyzer (Kodak, Japan).

Laboratory animal and breeding condition. Five-week old nude mice (Charles River Laboratories, Wilmington, MA, USA) were maintained in a thermo-hygrostat (Jeung Do B\&P Co., Korea) at $22-23^{\circ} \mathrm{C}$ and a relative humidity of $40-60 \%$. The mice were housed four mice/cage in a clean rack. The hall and sterile chamber was cleaned with Hibitan solutions every 7-10 days, and the straw was exchanged with sterile straw every 3-4 days. The researchers' hands were cleaned with $70 \%$ ethanol, and clean gloves were used.

Xenotransplantation of the SNU-1041 cancer cell line. After the cell concentration was diluted to $10^{8}$ cells $/ \mathrm{ml}$, the cells were injected into back of the nude mice aged 5 weeks using a 30 gauge $(\mathrm{G}), 1 \mathrm{ml}$ insulin syringe. The cancer volume was measured 3 times per week.

Cetuximab and results after photodynamic therapy. The mice were divided into four experimental groups after the cancer volume reached $100-300 \mathrm{~mm}^{3}$. The 1 st group $(n=10)$ was the control group. The 2nd group $(\mathrm{n}=10)$ was treated with $2 \mathrm{mg}$ (equal to $50 \mathrm{~kg}$ man) Cetuximab every 2 days for 3 weeks. The 3rd group $(n=10)$ was treated with photodynamic therapy using photofrin $(1 \mathrm{mg} / \mathrm{kg})$ diluted in DPBS fluid injected into the abdominal cavity through a 30 gauge $(\mathrm{G}) 1 \mathrm{ml}$ insulin syringe. After $24 \mathrm{~h}$, the cancer area was then exposed to $632 \mathrm{~nm}$ diode laser light at four directions for $5 \mathrm{~min}$. In Group 4, photodynamic therapy and Cetuximab were performed simultaneously. The other areas of the mice were blocked to prevent other complications. Photodynamic therapy was performed on the 1st day. A 2nd photodynamic therapy was performed on the 14th day for the mice with tumors that did not respond to the 1st photodynamic therapy. The anti-cancer effect was judged by measuring the volume of the tumor twice per week. The volume was calculated using the following formula:

$$
\mathrm{V}=(4 / 3 \times \mathrm{A} \times \mathrm{B} \times \mathrm{C}) \times 1 / 2
$$

(V, volume; $\mathrm{A}$, major axis; $\mathrm{B}$, minor axis; $\mathrm{C}$, height)

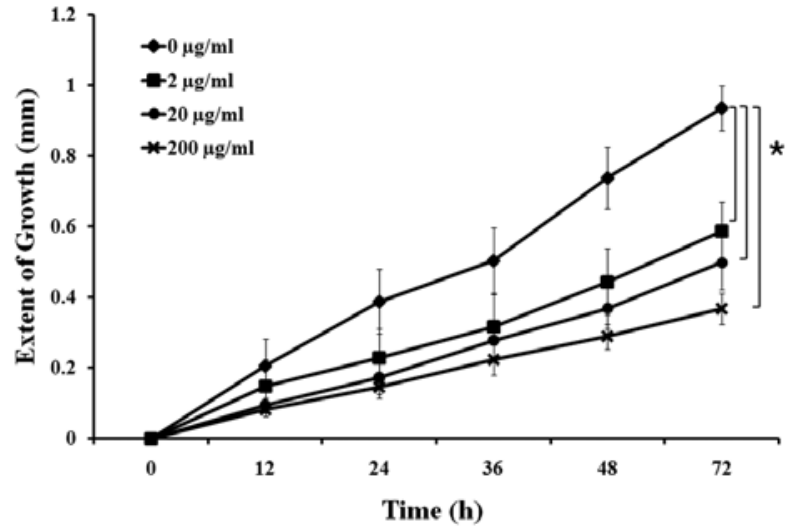

Figure 2. The effect of Cetuximab on the migration of SNU-1041 human head and neck squamous cancer cells. Migration was inhibited in SNU-1041 cells treated with Cetuximab in a dose-dependent manner.

Statistical analysis. The results are reported as the mean \pm SD. A t-test and paired t-test ANOVA test were performed for statistical analysis. A p $<0.05$ was considered significant.

\section{Results}

Anti-growth effect of Cetuximab on the SNU-1041 cells. The cell survival rate (Photoluminescence measurements) of the control group was converted to an average numerical value of $100 \%$. The survival rate of the cells treated with $3.9,31.3$, 250 and $500 \mu \mathrm{g} / \mathrm{ml}$ Cetuximab was 78.8, 64.1, 47.7 and 41\%, respectively. Overall, the cell survival rate decreased with increasing Cetuximab concentration. In addition, the rate of SNU-1041 cell proliferation decreased with increasing Cetuximab concentration ( $p<0.05$, Fig. 1).

Cell migration assay. The migration distance of a cell was measured at the lowest magnification using a digital camera. The image was then enlarged 4 times. The distance between the cells was measured. The whole distance minus the measured distance was defined as the migration distance. The migration distance was measured at 12, 24, 36, 48 and $72 \mathrm{~h}$. The migration distance of the control group was 0.2, 0.39 , $0.5,0.74$ and $0.94 \mathrm{~mm}$, respectively. The migration distance of the group treated with $2 \mu \mathrm{g} / \mathrm{ml}$ Cetuximab (Erbitux) was $0.15,0.23,0.32,0.44$ and $0.59 \mathrm{~mm}$, respectively. After $12 \mathrm{~h}$, there was no significant difference between the two groups. However, after $24 \mathrm{~h}$, there was a significant decrease in migration distance compared with the control group. In the group treated with $20 \mu \mathrm{g} / \mathrm{ml}$ Cetuximab, the migration distance decreased to $0.09,0.17,0.28,0.37$ and $0.50 \mathrm{~mm}$. The migration distance of the group treated with $200 \mu \mathrm{g} / \mathrm{ml}$ Cetuximab after $12 \mathrm{~h}$ was $0.08,0.15,0.22,0.29$ and $0.37 \mathrm{~mm}$, and was significantly lower than the control group $(\mathrm{p}<0.05$, Fig. 2 and 3).

The photodynamic therapy in SNU-1041 cell line and the synergistic cytotoxic effect of combined therapy with Cetuximab. The cell survival rate of the group given the combined photodynamic therapy with $3.9 \mu \mathrm{g} / \mathrm{ml}$ Cetuximab was measured. The cell survival rate was very low when a high concentration of photofrin was used. However, when 
A
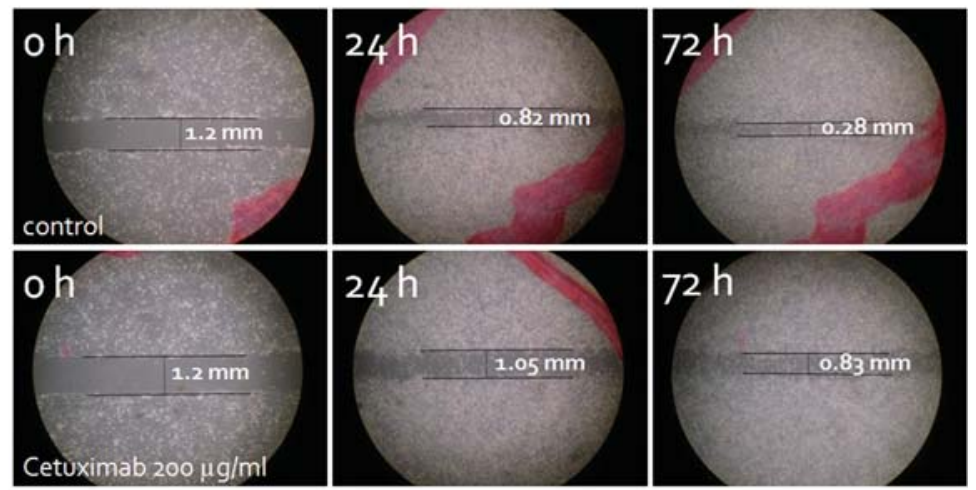

B

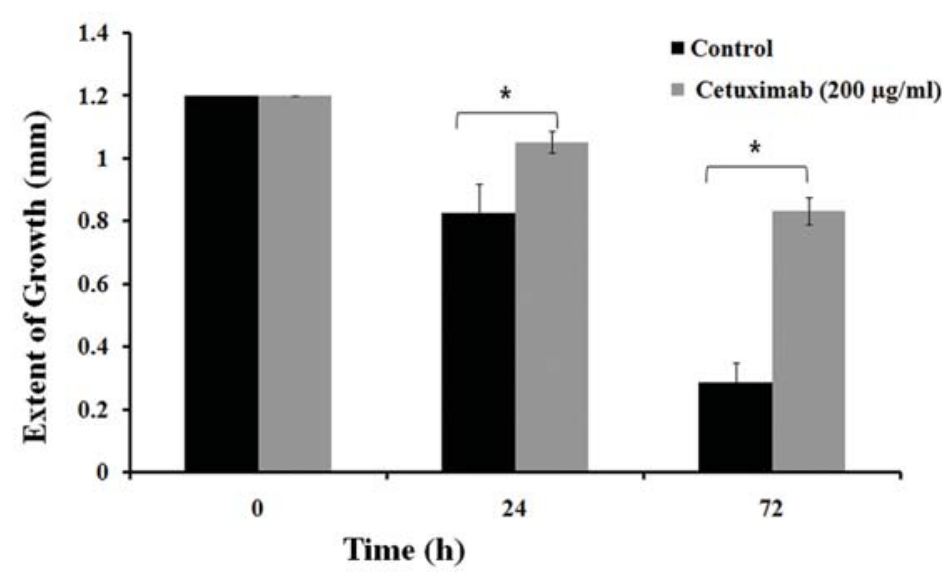

Figure 3. The effect of Cetuximab on the migration of SNU-1041 human head and neck squamous cancer cells. Migration was significantly suppressed in the SNU-1041 cells treated with $200 \mu \mathrm{g} / \mathrm{ml}$ of Cetuximab compared with control morphologically.

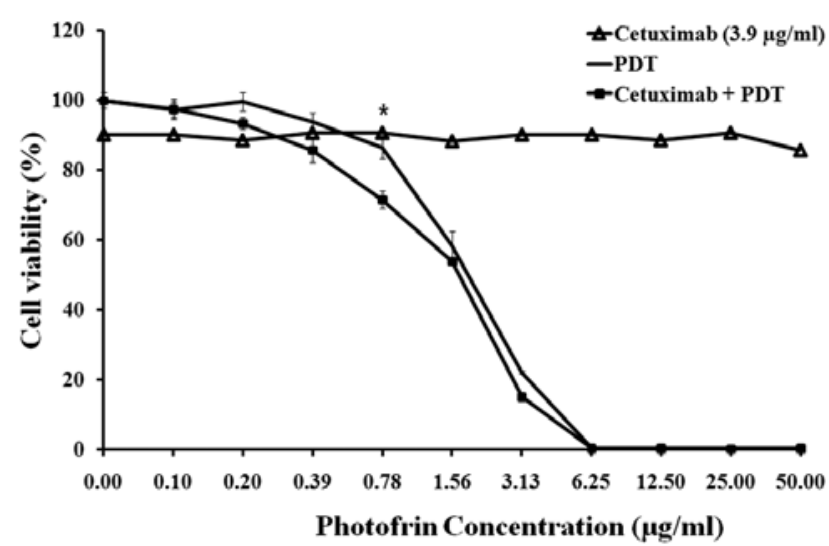

Figure 4. The antiproliferative effect of Cetuximab and PDT in SNU-1041 human head and neck squamous cancer cells. The cell viability after combination treatment with Cetuximab $(50 \mu \mathrm{g} / \mathrm{ml})$ and PDT was decreased in the SNU-1041 cells.

lower concentrations of photofrin were used, the cell survival rate decreased in a concentration-dependent manner. In particular, the cell survival rate was $98,93,85$ and $71 \%$ when $0.1,0.2,0.39$ and $0.78 \mu \mathrm{g} / \mathrm{ml}$ photofrin was used in conjunction with $3.9 \mu \mathrm{g} / \mathrm{ml}$ Cetuximab. Combined photodynamic therapy with Cetuximab decreased the

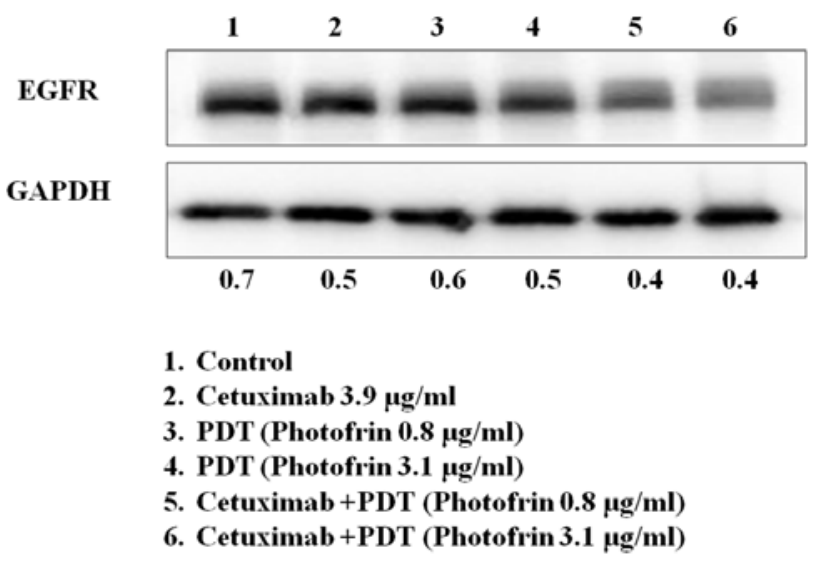

Figure 5. The expression of EGFR in SNU-1041 human head and neck squamous cancer cells treated with the combination therapy. The EGFR of SNU-1041 cells was inhibited by the combination treatment of Cetuximab and PDT.

survival rate at low concentrations of photofrin. In comparison, cell survival rate of the group treated with photodynamic therapy only was $97,99,94$ and $86 \%$, respectively. The cell survival rate was significantly lower when the cells were treated with photodynamic therapy combined with Cetuximab and $0.78 \mu \mathrm{g} / \mathrm{ml}$ photofrin than those treated with photodynamic therapy or Cetuximab 


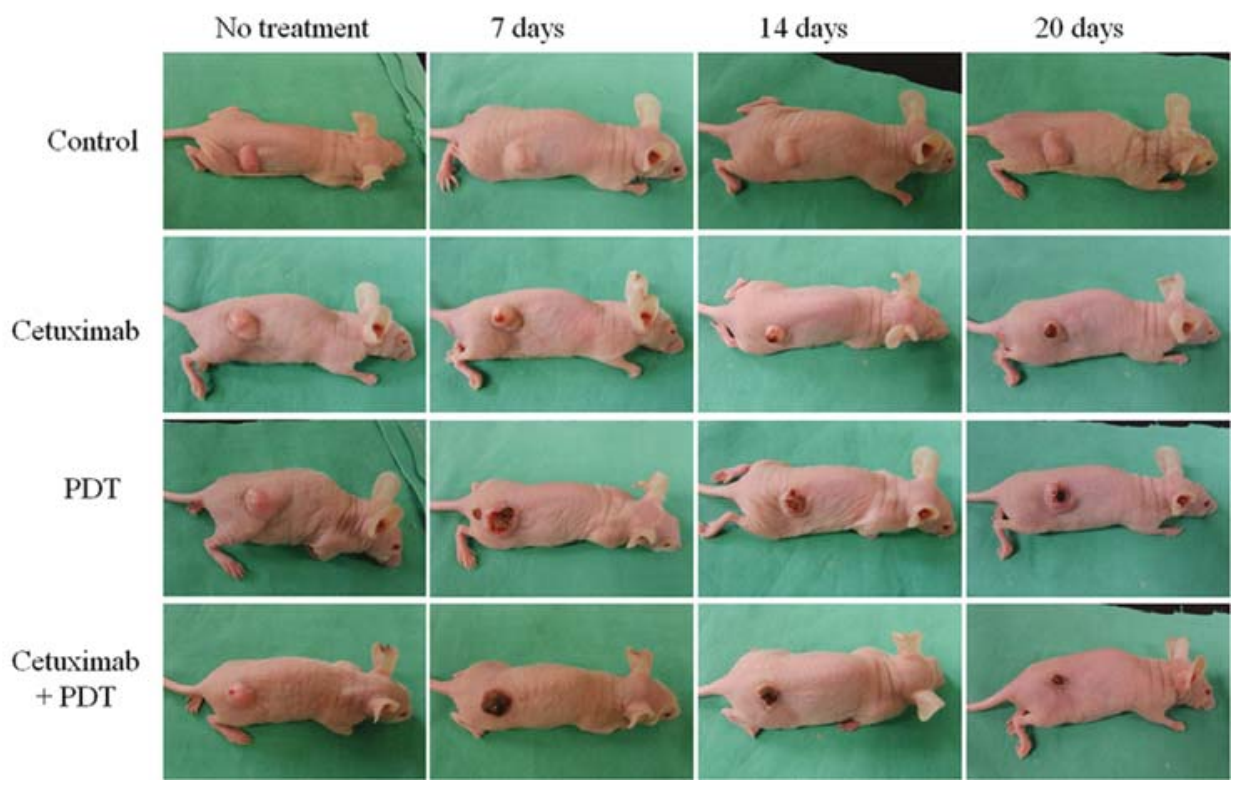

Figure 6. The effect of the combination therapy with Cetuximab and PDT on the tumor volume in a xenograft model.

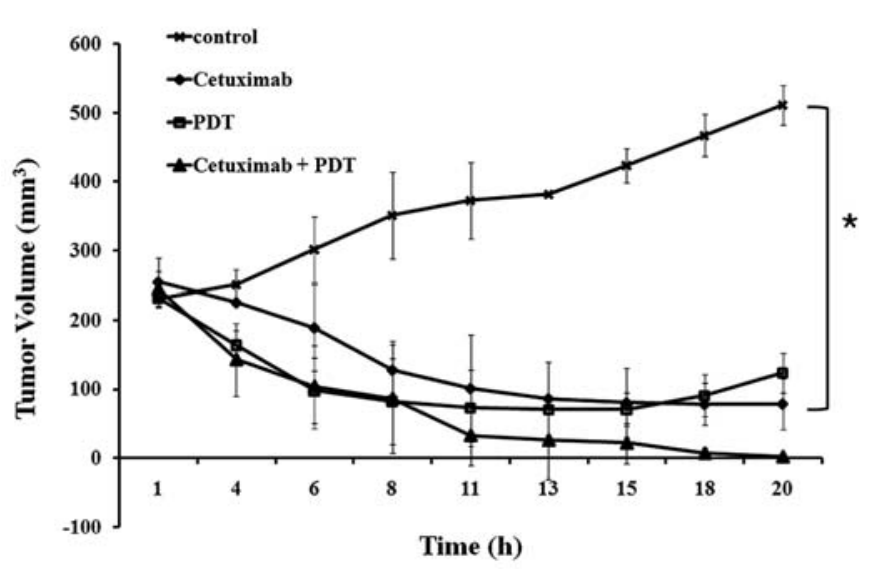

Figure 7. The effect of the combination therapy with Cetuximab and PDT on the tumor volume in a xenograft model. The combination treatment of Cetuximab with PDT showed significant tumor growth inhibition in the xenograft model $(\mathrm{p}<0.05)$.

$(p<0.05$, Fig. 4). This demonstrates the effect of the combination treatment of photodynamic therapy with photofrin and Cetuximab as an EGFR antagonist on the SNU-1041 cell line in vitro.

Negative effect of photodynamic therapy on the SNU-1041 cell line and combination treatment with Cetuximab and photodynamic therapy to EGFR. A large amount of EGFR was found in the SNU-1041 cell line treated with Cetuximab only, photofrin 0.8 and $3.1 \mu \mathrm{g} / \mathrm{ml}$ photodynamic therapy, and the control group. However, the group treated with combination treatment showed a low level of EGFR depending on the photofrin concentration used (Fig. 5).

Effect of the combination Cetuximab and photodynamic therapy on the transplanted cell line (in vivo study). Analysis of the combined effect of Cetuximab and photodynamic therapy was performed using an experimental animal (nude mouse) model in vivo. The cancer volume after injecting cancer cells in the control group increased from 252.5 to $300.8 \mathrm{~mm}^{3}, 423 \mathrm{~mm}^{3}$ and $511 \mathrm{~mm}^{3}$ after 6,14 and 20 days, respectively. The cancer volume after injecting the cancer cells in the Cetuximab group decreased from $231 \mathrm{~mm}^{3}$ at start of treatment to $188.6,79.8$ and $78.1 \mathrm{~mm}^{3}$ after 6,15 and 20 days, respectively. The cancer volume was significantly lower than the control group. The cancer volume after injecting the cancer cells in the photodynamic therapy group decreased from $181.1 \mathrm{~mm}^{3}$ at the start of treatment to $97.5 \mathrm{~mm}^{3}, 70.5$ and $123.2 \mathrm{~mm}^{3}$ after 6,15 and the last day, respectively. The cancer volume after injecting the cancer cells to the combination treatment with Cetuximab and photodynamic therapy group decreased from $143.4 \mathrm{~mm}^{3}$ at the start of treatment to $103.2 \mathrm{~mm}^{3}, 20.9$ and $1.2 \mathrm{~mm}^{3}$ after 6 , 15 and 20 days, respectively. Overall, the combined treatment had a significantly greater effect than the individual treatments $(\mathrm{p}<0.05$, Fig. 6 and 7$)$.

\section{Discussion}

PDT has been studied extensively as an anticancer treatment from 1970. In this treatment, a photosensitizer that is absorbed well by cancer cells is injected into the cancer and activated by a specific wavelength. A photosensitizer is essential for carrying out photodynamic therapy because it is activated by light of a specific wavelength. A laser is used mainly in photodynamic therapy because it has sufficient energy to activate the photosensitizer compared with other light sources, and can emit light of a single wavelength. Hence, it can produce the maximum activity of the photosensitizer.

Currently, a diode laser with a continuous wavelength (CW) is used universally for photodynamic therapy. The diode laser used in this study had a wavelength of $632 \mathrm{~nm}$, which is the maximum absorption spectrum of photosensitizer 
sufficient to produce a maximum treatment effect. It is possible that there will be a difference in cytotoxic effect according to the Laser radiation method. The pulse method is more effective in killing tumor cells without damaging normal cells (20). Laser in pulsed mode generally has deeper penetration than a CW Laser and has a lower temperature. Therefore, it is believed to be more suitable for photodynamic therapy.

The start of action electric generation within the cell by photodynamic therapy is understood to be a phenomenon of photophysics. A photosensitizer in the ground state (S0) is activated by a specific wavelength, and excited to the singlet (S1) or triplet state (T1). At this time, the energy that is released when with the floor state reacts with oxygen produces an oxygen free radical (type II reaction), which causes cell destruction. On the other hand, photosensitizer is involved in the electron transport system (type I reaction), which causes cell destruction.

The type I response occurs mainly in polar culture media, and the type II response occurs mainly in high $\mathrm{O}_{2}$ lipophilic environments. Therefore, the type II response is used mainly in photodynamic therapy. However, Ochsner reported that type II responses can change to type I responses in situations where local hypoxia is caused $(24,25)$.

In addition, while ATP storage runs dry in a cell as a result of direct cell membrane damage (26), the progress process of necrosis occurring after photodynamic therapy impedes cell reproduction or the rehabilitation process, reduces the level of amino acid movement into cells (27), or decrease of the $\mathrm{pH}$ in a cell (28). The destruction of a tumor cell and the resulting necrosis due to damage to the lysosome membrane causes the dissociation of a large amount of proteinase (29). According to this phenomenon, damage to the cell membrane causes failure of the arachidonic acid metabolism as well as blood vessel injury. Necrosis is accelerated by stimulation of the complement system as well as the excretion of histamine and other inflammatory materials (30). Direct cell damage induces an imbalance of the proteins transmitting ions through the cell membrane (31). The level of endonuclease is increased when the level of calcium within the cell increases, which causes calcium dependent necrosis, i.e. DNA decomposition (32). This is not observed in all cases after photodynamic therapy, and this type of necrosis is dependent on the type of photosensitizer and target cell line (33).

The advantage of photodynamic therapy is the virtual lack of pain. It is performed simultaneously with chemotherapy, radiotherapy and surgery. In addition, there is no limit to the number of times photosensitizer injection or laser therapy can be performed, so a continuous procedure is possible. Photodynamic therapy is suitable for superficial cancers because the absorption wavelength of most photosensitizers (including photofrin) used in these cases is $630 \mathrm{~nm}$, and the permeability of a laser is $0.5-1 \mathrm{~cm}$.

A total of 171 examples have been reported since Keller et al (34) presented 3 examples of complete remission of oral cavity cancers. Of these, photodynamic therapy was used to treat 145 examples $(85 \%)$ of early stage head and neck cancer. Freche et al (36) reported the complete remission of early stage laryngeal cancer in 25 patients (78\%) with $\mathrm{T} 1$ or less out of 32 examples. Biel et al (37) reported the complete remission of 25 squamous cell cancer examples with T1. However, 17 examples relapsed after radiotherapy. Schweitzer (38) reported 8 cases of complete remission of squamous cell cancer out of 10 examples with T1 and T2. Six out of the 10 cases relapsed. Two cases with T1 that relapsed after LMS with a laser showed complete remission. Of the remaining 4 cases, 1 case with T1 relapsed after radiotherapy and 3 cases with $\mathrm{T} 2$ relapsed after radiotherapy. After treatment, 3 of these 4 cases showed complete remission.

The main systemic side effects of photodynamic therapy are photosensitivity that persists for 4-6 days. The patients are asked to avoid direct sunlight and direct light when inside during these periods because skin burns, and blisters can occur. In addition, some pain, slight fever, an increase in urination frequency can occur. This treatment is not recommended for patients showing photosensitivity, poor kidney or poor liver function. The photosensitizer is injected slowly at 15-20 drops per minute and is mixed with $40 \mathrm{cc}$ of normal saline. There is a 15-20 min break after injecting the first $10 \mathrm{cc}$ to determine if there an abnormal response.

In this study, the size of the tumor in the animal experiment was reduced more with the combination therapy (EGFR interception and photofrin-PDT) than with the individual treatments. This shows that the treatments act synergistically through two different molecular pathways, as suggested elsewhere $(41,42)$.

Under normal conditions, the manifestation of EGFR is important for the physiology of a cell using receptor tyrosine kinase. One is the RTK-Grb2-Sos-Ras cascade, which is activated by mitogen-activated protein kinase and phosphatidylinositol3-kinase. The manifestation of these two pathway conversions affects the proteins that induce cell division. The overexpression by cancer cells is increased by Cyclin-D and Myc, phosphorylation of the retinoblastoma protein, activation of factor $4 \mathrm{E}$ and a decrease in $\mathrm{p} 27$. It is believed that these adjustment proteins disregard the check point, and exhibit the malignancy of an organization by causing the unfit conversion of G1 to S. However, there is the possibility of impeding the progress by suppressing the activity of EGFR. Cells are dependent more on this proliferative pathway after being damaged by photodynamic therapy.

Overexpressed EGFR is common to cancers with considerable resistance to existing treatments or is progressed. On the other hand, PDT is used experimentally in nonreactive chemotherapy and radiotherapy. The union of PDT and an EGFR immune treatment can solve the small issues of each individual treatment. For example, Cetuximab is mainly a cytostatic treatment. Therefore, a long treatment period is needed. However, there are frequent relapses, and drug intoxication. Photodynamic therapy is also a cytotoxic treatment but there is the possibility of residual cancer remaining in cases of single treatments and there are no criteria for use. Therefore, a combined treatment can have an excellent better anticancer effect than the independent treatments despite reduced capacity of Cetuximab or the photosensitizer.

The cell toxicity of photofrin in this study was confirmed by the decrease in cell survival at high concentrations. 
Hence, the effective distribution of the photosensitizer in a cell is more important than the concentration (43). Cytotoxicity increases in direct proportion to the energy supplied. Therefore, it is believed that there is an increase in the photophysical phenomenon, which can react with the photosensitizer. This is an important element to be considered in photodynamic therapy. An adequate response time of the photosensitizer in a cell will result in effective treatment.

In conclusion, this study compared the treatment effectiveness of a combined treatment with Cetuximab and PDT with the effects of the individual treatments using in vivo and in vitro experiments. A combination of a suitable ratio of biological and photodynamic therapy can be effective in treating malignant tumors and should be considered as a treatment.

However, more cases and a standardized study will be needed to confirm these results. Photodynamic therapy is not confined to an adjuvant therapy and palliative therapy of an existing treatment, and it is believed that photodynamic therapy should be the initial treatment for head and neck cancers and recurrences.

\section{Acknowledgements}

We are thankful for financial support from the Medical Laser Research Center of Dankook University.

\section{References}

1. Yoo YS, Seo M, Woo HY, Lee CH and Choi JH: Expression of p53, PCNA, EGFR in rat submandibular gland tumor induced experimentally. Korean J Otolaryngol-Head Neck Surg 43: 631-637, 2000

2. Libermann TA, Nusbaum HR, Razon N, Kris R, Lax I, Soreq H, Whittle N, Waterfield MD, Ullrich A and Schlessinger J: Amplification, enhanced expression and possible rearrangement of EGF receptor gene in primary human brain tumors of glial origin. Nature 313: 144-147, 1985.

3. Gusterson B, Cowley G, Smith JA and Ozanne B: Cellular localisation of human epidermal growth factor receptor. Cell Biol Int Rep 8: 649-658, 1984.

4. Cowley G, Smith JA, Gusterson B, Hendler F and Ozanne B: The amount of EGF receptor is elevated on squamous cell carcinoma. Cancer Cells 1: 5-10, 1984

5. Kamata N, Chida K, Rikimaru K, Horikoshi M, Enomoto S and Kuroki T: Growth inhibitory effects of epidermal growth factor and overexpression of its receptors on human squamous cell carcinomas in culture. Cancer Res 46: 1648-1653, 1986.

6. Calvo E and Rowinsky EK: Clinical experience with monoclonal antibodies to epidermal growth factor receptor. Curr Oncol Rep 7: $96-103,2005$

7. Kim ES, Vokes EE and Kies MS: Cetuximab in cancers of the lung and head \& neck. Semin Oncol 31: 61-67, 2004.

8. Ciardiello F, Bianco R, Damiano V, De Lorenzo S, Pepe S, De Placido S, Fan Z, Mendelsohn J, Bianco AR and Tortora G: Antitumor activity of sequential treatment with topotecan and anti-epidermal growth factor receptor monoclonal antibody C225. Clin Cancer Res 5: 909-916, 1999.

9. Huang SM, Bock JM and Harari PM: Epidermal growth factor receptor blockade with $\mathrm{C} 225$ modulates proliferation, apoptosis, and radiosensitivity in squamous cell carcinoma of the head and neck. Cancer Res 59: 1935-1940, 1999.

10. Buchsbaum DJ, Bonner JA, Grizzle WE, Stackhouse MA, Carpenter M, Hicklin DJ, Bohlen P and Raisch KP: Treatment of pancreatic cancer xenografts with Erbitux anti-EGFR antibody, gemcitabine, and radiation. Int J Radiat Oncol Biol Phys 54: 1180-1193, 2002.

11. Bonner JA, Harari PM, Giralt J, Azarnia N, Cohen RB, Raben D, Jones C, Kies MS, Baselga J and Ang KK: Cetuximab prolongs survival in patients with locally advanced squamous cell carcinoma of head and neck: a phase III study of high dose radiation therapy with and without Cetuximab. Proc Am Soc Clin Oncol, Abst. 5507, 2004.

12. Cunningham D, Humblet Y, Siena S, Khayat D, Bleiberg H, Santoro A, Bets D, Mueser M, Harstrick A, Verslype C, Chau I and Van Cutsem E: Cetuximab monotherapy and Cetuximab plus irinotecan-refractory metastatic colorectal cancer. N Engl J Med 351: 337-345, 2004.

13. Dougherty TJ, Gomer CJ, Henderson BW, Jori G, Kessel D, Korbelik M, Moan J and Peng Q: Photodynamic therapy. J Natl Cancer Inst 90: 889-905, 1998.

14. Kim JS, Chung PS, Lee SJ, Oh CH, Chung SY, Park JY and Kim JS: The photodynamic therapy using 5-aminolevulinic acid: The study of the anti-tumor effect on in vitro and in vivo experiments. Korean J Otolaryngol-Head Neck Surg 48: 234-240, 2005.

15. Del Carmen MG, Rizvi I, Chang Y, Moor AC, Oliva E, Sherwood M, Poque B and Hasan T: Synergism of epidermal growth factor receptor-targeted immunotherapy with photodynamic treatment of ovarian cancer in vivo. J Natl Cancer Inst 97: 1516-1524, 2005.

16. Wood SR, Holroyd JA and Brown SB: The subcellular localization of $\mathrm{Zn}$ (II) phthalocyanines and their redistribution on exposure to light. Photochem Photobiol 65: 397-402, 1997.

17. Berg K and Moan J: Lysosomes and microtubles as targets for photochemotherapy of cancer. Photochem Photobiol 65: 403-409, 1997.

18. Noodt BB, Berg K, Stokke T, Peng Q and Nesland JM: Apoptosis and necrosis induced with light and 5-aminolaevulinic acid- derived protoporphyrin IX. Br J Cancer 74: 22-29, 1996.

19. Gomer CJ, Rucker N, Ferrario A and Wong S: Properties and applications of photodynamic therapy. Radiat Res 120: 1-18, 1989.

20. Muller S, Walt H, Dobler-Girdziunaite D, Fiedler D and Haller U: Enhanced photodynamic effects using fractionated laser light. J Photochem Photobiol B 42: 67-70, 1998.

21. Moan J and Berg K: The photodegradation of porphrins in cells can be used to estimate the lifetime of singlet oxygen. Photochem Photobiol 53: 549-553, 1991.

22. Foote CS: Type I and Type II mechanisms of photodynamic action. In: Light-Activates Pesticides. ACS Symposium Series No. 339. Hietz JR and Downum KR (eds). American Chemical Society, Washington DC, pp22-38, 1987.

23. Tomio L, Reddi E, Jori G, Zorat P, Pizzi GB and Calzavara F: Hematoporphyrin as a sensitizer in tumor phototherapy: effect of medium polarity on the photosensitizing efficiency and role of the administration pathway on the distribution in normal and tumor-bearing rats. Springer Ser Opt Sci 22: 76-82, 1980.

24. Ochsner M: Photophysical and photobiological processes in the photodynamic therapy of tumors. J Photochem Photobiol B 39: $1-18,1997$.

25. Melo CA, Kurachi C, Grecco C, Sibata CH, Castro-e-Silva O and Bagnato VS: Pharmacokinetics of photogem using fluorescence monitoring in Wistar rats. J Photochem Photobiol B 73:183-188, 2004.

26. Gibson SL, Ceckler TL, Bryant TG and Hilf R: Effects of laser photodynamic therapy on tumor phosphate levels and $\mathrm{pH}$ assessed by 31P-NMR spectroscopy. Cancer Biochem Biophys 10: 319-328, 1989.

27. Newsholme EA and Leech AR: Biochemistry for the medical sciences. John Wiley and Sons, Chichester, pp300-304, 1984

28. Hetzel FW and Chopp M: Modifications in intratumor microenvironment with PDT. SPIE 1065: 41-47, 1989.

29. Milanesi C, Zhou C, Biolo R and Jori G: Zn(II)-phthaocyanine as photodynamic agent for tumors. II. Studies on the mechanism of photosensitized tumor necrosis. Br J Cancer 61: 846-850, 1990.

30. Lim HW: Role of mediators of inflammation in cells on porphyrin induced phototoxicity. SPIE Proc 1065: 28-33, 1989.

31. Specht KG and Rodgers MA: Depolarization of mouse myeloma cell membranes during photodynamic action. Photochem Photobiol 51: 319-324, 1990.

32. McCabe MJ Jr, Nicotera P and Orrenius S: Calcium dependent cell death: Role of the endonuclease, protein kinase $C$ and chromatin formation. Ann NY Acad Sci 663: 269-278, 1992.

33. Wyld L, Reed MW and Brown NJ: Differential cell death response to photodynamic therapy is dependent on dose and cell type. Br J Cancer 84: 1384-1386, 2001. 
34. Wilson BD, Mang TS, Stoll H, Jones C, Cooper M and Dougherty TJ: Photodynamic therapy for the treatment of basal cell carcinoma. Arch Dermatol 128: 1597-1601, 1992.

35. Biel MA: Photodynamic therapy and the treatment of head and neck neoplasia. Laryngoscope 108: 1259-1268, 1998.

36. Freche $\mathrm{C}$ and De Corbiere S: Use of photodynamic therapy in the treatment of vocal cord carcinoma. J Photochem Photobiol B 6: 291-296, 1990.

37. Biel MA: Photodynamic therapy and the treatment of neoplastic diseases of the larynx. Laryngoscope 104: 399-403, 1994.

38. Schweitzer VG: PHOTOFRIN-mediated photodynamic therapy for treatment of early stage oral cavity and laryngeal malignancies. Lasers Surg Med 29: 305-313, 2001.

39. Kim YK, Park HK, Hyun JH, Kim JH and Cho BH: Photodynamic therapy for early tongue cancer. J Korean Assoc Oral Maxillofac Surg 24: 222-225, 1998.
40. Kim YK, Lee YM, Kim KU, Uh ST, Kim YH and Park CS: Clinical experience of photodynamic therapy in five patients with advanced lung cancer. Tuberc Respir Dis 57: 72-77, 2004.

41. Chabner BA: Cytotoxic agents in the era of molecular targets and genomics. Oncologist 7: 34-41, 2002.

42. Mendelsohn J: Epidermal growth factor receptor inhibition by a monoclonal antibody as anticancer therapy. Clin Cancer Res 3: 2703-2707, 1997.

43. He J, Horng MF, Deahl JT, Oleinick NL and Evans HH: Variation in photodynamic efficacy during the cellular uptake of two phthalocyanine photosensitizers. Photochem Photobiol 67 : 720-728, 1998. 